Notes

\title{
Experimental Transfer of Tetracycline Resistance Genes from Fish-derived Bacteria to Escherichia coli
}

\author{
Seok-Ryel Kim ${ }^{1, *}$, Hyeung-Rak Kim ${ }^{1}$ and Satoru Suzuki ${ }^{2}$ \\ ${ }^{1}$ Division of Food Science and Biotechnology, Pukyong National University, Busan 608-737, Korea \\ ${ }^{2}$ Center for Marine Environmental Studies (CMES), Ehime University, Matsuyama 790-8577, Japan
}

\begin{abstract}
To determine whether the tetracycline resistance genes tet (34), tet $(\mathrm{M})$, and tet $(\mathrm{S})$ can be transferred among bacteria, we used a filter mating experiment allowing intimate cell-cell contact between donor and recipient. The tet (34) gene, conveyed on a chromosome of Vibrio species (No. 6 and SW-42) was not transferred to Escherichia coli JM109, suggesting that it is not transferred among bacterial species. The tet $(\mathrm{M})$ gene was transferred from three Vibrio strains (4-E, SW-18, and SW-38) to E. coli at frequencies of $8.5 \times 10^{-5}$ to $2.1 \times 10^{-6}$. The tet (S) gene was transferred from Lactococcus garvieae KHS98032 to E. coli at a frequency of $1.8 \times 10^{-6}$. Transconjugated recipients showed increased minimum inhibitory concentrations against oxytetracycline. Although the donors possess the $\operatorname{Tn} 916-\operatorname{Tn} 1545$ transposons, they were not detected in transformed recipients, suggesting that the transfer of tet $(\mathrm{M})$ and tet $(\mathrm{S})$ is mediated by elements or mechanisms. Two ribosomal protect protein genes were also transmissible from marine bacteria to $E$. coli, suggesting gene hopping among marine, terrestrial, and human environments.
\end{abstract}

Key words: Resistance gene, Tetracycline, tet (M), tet (S), tet (34), Escherichia coli

\section{Introduction}

Tetracycline (TC) has been widely used in aquaculture, and many studies have reported TC-resistant bacteria pathogenic to fish (Aoki et al., 1977; DePaola et al., 1988; Ho et al., 2000; Rhodes et al., 2000). The determinants of TC resistance are widespread among bacterial species worldwide (Levy, 1988; Chopra and Roberts, 2001). To date, 40 different tetracycline resistance genes (tet), including oxytetracycline (OTC) resistance genes (otr), have been registered in GenBank. It is well-known that resistance determinants can be transferred among bacteria by plasmids, transposons, and integrons in aquatic environments (Aoki et al., 1987; Salyers et al., 1995; Chandrasekaran et al., 1998). All of the TCresistance genes reported from aquatic bacteria are efflux genes, and none are ribosomal protect protein (RPP) genes. The distribution of tet (34), tet (M), and tet $(\mathrm{S})$ genes in bacteria isolated from fish and seawater has been described (Nonaka and Suzuki, 2002; Kim et al., 2003, 2004). A transposon was detected to

\footnotetext{
*Corresponding author: ksr0914@nate.com
}

accompany tet $(\mathrm{M})$, suggesting that the transfer of tet $(\mathrm{M})$ is mediated by a transposon (Clewell et al., 1995; De Barbeyrac et al., 1996; Rhodes et al., 2000). Gene transfer among marine bacteria may contribute to the maintenance and distribution of resistance genes in the marine environment. TC resistance genes that originated in human clinical and terrestrial bacteria are conveyed on plasmids or transposons, indicating that the resistance genes are mediated by these mobile elements (Clewell et al., 1995; Roberts, 1996). However, little is known about the mechanisms responsible for the transfer of tet genes in the marine environment. Here, we describe the possibility for the transfer of the tet (34), tet (M), and tet $(\mathrm{S})$ genes from marine isolates to Escherichia coli.

\section{Materials and Methods \\ Mating procedure \\ We performed a conjugation experiment to ex- amine the transfer of TC resistance genes from marine isolates to $E$. coli JM109 using the filter mating method (Sandaa et al., 1992). The tet donors}


were Vibrio species No. 6 and SW-42, which contain the tet (34) gene; Vibrio species 4-E, SW-18, and SW-38, which contain the tet $(\mathrm{M})$ gene; and Lactococcus garvieae KHS98032, which contains the tet $(\mathrm{S})$ gene. The donor strains were grown on nutrient salt agar (NSA: Nonaka and Suzuki, 2002) plates supple-mented with $1 \% \quad \mathrm{NaCl}$ and $32 \mu \mathrm{g} / \mathrm{mL}$ oxytetracycline (OTC; Sigma Chemical Co, St. Louis, MO, USA) at $25^{\circ} \mathrm{C}$. The recipient $E$. coli JM109 was grown on Luria-Bertani (LB: Difco, Detroit, MI, USA) medium at $37^{\circ} \mathrm{C}$. The donors and recipient were grown to the exponential growth phase in $2 \mathrm{~mL}$ of NSA without agar, in which the salt concentration was $1 \%$. The cell density of each culture was adjusted to $10^{8}$ cells $/ \mathrm{mL}$. Equal volumes of the donor and recipient cultures were mixed; $1 \mathrm{~mL}$ of the mixture was spotted on a $47-\mathrm{mm}$-diameter HA membrane filter $(0.45-\mu \mathrm{m}$ pore size: Millipore, Bedford, MA, USA) placed on NSA medium. After incubation at $25^{\circ} \mathrm{C}$ for $24 \mathrm{~h}, E$. coli that had received the tet gene from the donor was selected as follows. The filter was transferred into $2 \mathrm{~mL}$ of A-14 buffer $(39.3 \mathrm{mM}$ $\mathrm{Na}_{2} \mathrm{HPO}_{4}, 22.0 \mathrm{mM} \mathrm{KH} \mathrm{PO}_{4}, 68.5 \mathrm{mM} \mathrm{NaCl}, 0.8$ $\mathrm{mM} \mathrm{MgSO}, \mathrm{pH} 7.2$ ) and stirred. The solution was diluted, and $100 \mu \mathrm{L}$ was spread on LB plates supplemented with $20 \mu \mathrm{g} / \mathrm{mL}$ OTC. The plates were incubated at $42^{\circ} \mathrm{C}$ to suppress the growth of the donor stain. PCR was used to detect the target tet gene as described by Kim et al. (2004) to confirm the transfer of the tet gene to the recipient $E$. coli.

\section{Determination of minimum inhibitory concentra- tion}

The minimum inhibitory concentration (MIC) of oxytetracycline for donors and recipients were measured as follows. The bacterial cell suspension was prepared in phosphate-buffered saline (PBS), and the cell density was adjusted to MacFarland No. 0.5. A 1$\mu \mathrm{L}$ aliquot of the suspension was spotted on MuellerHinton medium (Difco) plates supplemented with $1.5 \% \mathrm{NaCl}$ containing $15,30,60$, and $120 \mu \mathrm{g} / \mathrm{mL}$ OT C. The plates were incubated at $25^{\circ} \mathrm{C}$ for $48 \mathrm{~h}$, and the lowest OTC concentration required for inhibition was recorded.

\section{Mating experiment}

\section{Results}

We recorded the transfer frequencies of the tet genes (Table 1). Transfer of tet genes was successful for four of the six donor strains: the three Vibrio strains containing the tet $(\mathrm{M})$ gene (4-E, SW-18, and SW-38), and L. garvieae (KHS98032) containing the tet (S) gene. The transfer of tet(34) from Vibrio species (No. 6 and SW-42) to E. coli was not successful. The transfer frequency ranged from $8.5 \times 10^{-5}$ to $2.1 \times 10^{-6}$ for tet $(\mathrm{M})$, and was $1.8 \times 10^{-6}$ for tet $(\mathrm{S})$. The Tn916 transposon was not detected in E. coli transconjugants (Table 1).

\section{Minimum inhibitory concentrations}

The MICs for donor strains were $\geq 120 \mu \mathrm{g} / \mathrm{mL}$ OTC, but those of recipient strains were $<5 \mu \mathrm{g} / \mathrm{mL}$ OTC. However, transconjugants with the tet $(\mathrm{M})$ or tet (S) genes had higher MICs. The transfer of tet (M) to $E$. coli resulted in an MIC $\geq 120 \mu \mathrm{g} / \mathrm{mL}$ OTC, whereas the transfer of tet (S) to $E$. coli showed an MIC of $60 \mu \mathrm{g} / \mathrm{mL}$ OTC (Table 2).

Table 1. Transfer rate in the mating experiment

\begin{tabular}{|c|c|c|c|c|c|c|c|}
\hline \multirow{2}{*}{ Donor strain } & \multirow{2}{*}{ Origin } & \multirow{2}{*}{$\begin{array}{c}\text { Resistance } \\
\text { gene }\end{array}$} & \multirow{2}{*}{ Tn916 } & \multirow{2}{*}{ Recipient strain } & \multicolumn{2}{|c|}{ After conjugation } & \multirow{2}{*}{ Transfer rate } \\
\hline & & & & & Detected gene & $\operatorname{Tn} 916$ & \\
\hline Vibrio No. $6^{a}$ & Yellowtail $(I)^{\mathrm{b}}$ & tet $(34)$ & - & E. coli JM109 & $N^{c}$ & - & -- \\
\hline Vibrio SW-42 & Seawater & tet $(34)$ & - & E. coli JM109 & ND & - & -- \\
\hline Vibrio 4-E & Yellowtail (I) & tet $(\mathrm{M})$ & - & E. coli JM109 & tet $(\mathrm{M})$ & - & $1.2 \times 10^{-5}$ \\
\hline Vibrio SW-18 & Seawater & tet $(\mathrm{M})$ & - & E. coli JM109 & tet $(\mathrm{M})$ & - & $8.5 \times 10^{-5}$ \\
\hline Vibrio SW-38 & Seawater & tet $(\mathrm{M})$ & - & E. coli JM109 & tet (M) & - & $2.1 \times 10^{-5}$ \\
\hline Lactococcus garvieae & Yellowtail (I) & tet $(\mathrm{S})$ & - & E. coli JM109 & tet $(S)$ & - & $1.8 \times 10^{-5}$ \\
\hline
\end{tabular}

${ }^{\mathrm{a}}$ Strain name; ${ }^{\mathrm{b}} \mathrm{I}$, intestine; ${ }^{\mathrm{N} D}$, not detected.

Table 2. MIC of donors and recipient strain

\begin{tabular}{lcccc}
\hline Donor strain & Resistance gene & MIC $(\mu \mathrm{g} / \mathrm{mL}$ OTC) & Transconjugant & MIC $(\mu \mathrm{g} / \mathrm{mL}$ OTC) \\
\hline & & & E. coli JM109 (negative control) & $<5$ \\
Vibrio 4-E & tet $(\mathrm{M})$ & $>120$ & Trans E. coli 4-E & $>120$ \\
Vibrio SW-18 & tet $(\mathrm{M})$ & $>120$ & Trans E. coli SW-18 & $>120$ \\
Vibrio SW-38 & tet $(\mathrm{M})$ & 120 & Trans E. coli SW-18 & 120 \\
Lactococcus garvieae KHS98032 & tet (S) & $>120$ & Trans E. coli KHS98032 & 60 \\
\hline
\end{tabular}




\section{Discussion}

We previously described the distribution of the TC resistance genes tet $(34)$, tet $(\mathrm{M})$, and tet $(\mathrm{S})$ among bacteria isolated from fish and seawater sampled from coastal aquaculture sites in the Philippines, Korea, and Japan between 1997 and 2002 (Kim et al., 2003, 2004). Here, we showed that TC resistance genes tet $(\mathrm{M})$ and tet $(\mathrm{S})$ can be transferred to $E$. coli from Vibrio species and L. garvieae under cell-cell contact.

The tet (34) gene, however, was not transferred to $E$. coli. A previous $16 \mathrm{~S}$ rDNA analysis showed that all tet (34)-positive strains were $100 \%$ identical (Kim et al., 2003). Nonaka and Suzuki (2002) reported that tet (34) was detected in certain Vibrio species, but not in other fish-related bacteria, such as Edwardsiella tarda, L. garvieae, or Photobacterium damsela subsp. piscicida. The tet (34) gene occurs on a chromosome of Vibrio species No. 6 (Nonaka and Suzuki (2002). Thus, evidence suggests that tet (34) is a specific gene in certain Vibrio species and is not transferred to other bacterial species. However, the tet (34) gene was recently detected from species of Pseudomonas and Serratia (Miranda et al., 2003). Moreover, it can be transferred from Pseudomonas pseudoalcaligenes and Serratia liquefaciens to $E$. coli at frequencies of $5.0 \times 10^{-5}$ and $1.3 \times 10^{-6}$ per recipient (Miranda et al., 2003). Because Miranda et al. (2003) did not sequence the tet (34) gene, we do not know if it is the same tet (34) gene identified by Nonaka and Suzuki (2002), who reported that tet (34) is similar to xanthine-guanine phosphoribosyl transferase (XPRT), an enzyme involved in GTP synthesis. Miranda et al. (2003) also detected other genes similar to XPRT.

The tet (M) gene is often associated with conjugative chromosomal elements such as transposons (Clewell et al., 1995; Salyers et al., 1995). However, we could not detect the Tn916 transposon in the transconjugant. All the donors we used carry the tet gene on a chromosome. We could not determine the mechanism of tet $(\mathrm{M})$ transfer. The $\mathrm{Tn} 916$ family consists of $\operatorname{Tn} 916, \operatorname{Tn} 918, \operatorname{Tn} 919, \operatorname{Tn} 920, \operatorname{Tn} 925$, Tn1545, Tn3702, Tn3703, Tn3704, Tn5251, Tn5381, Tn5383, Tn5397, and others. All of these elements may accompany the tet $(\mathrm{M})$ gene on a chromosome (Clewell et al., 1995; De Barbeyrac et al., 1996; Rice, 1998). Polymerase chain reaction (PCR) for Tn can detect the $\operatorname{Tn} 916$ and $\operatorname{Tn} 1545$ transposons because they are similar and have a similar Int-Tn gene encoding the integrases of the transposon. However, other transposon series could not be detected using PCR analysis. Therefore, conjugative transposons other than $\operatorname{Tn} 916$ and $\operatorname{Tn} 1545$ may mediate the transfer of $\operatorname{tet}(\mathrm{M})$.

The tet(S) gene has been detected in Listeria monocytogenes BM4210, where it is carried by selftransferable plasmids (Charpentier et al., 1994; Charpentier and Courvalin 1999). Lactococcus lactis also carries tet $(\mathrm{S})$ on a conjugative plasmid (Perreten et al., 1997). In Enterococcus faecalis, tet (S) is integrated into the chromosomal DNA (Charpentier et al., 1994; Francois et al., 1997). We found that tet (S) was transferred from $L$. garvieae to $E$. coli at a frequency of $1.8 \times 10^{-6}$. We did not find any plasmids in either the donor or transconjugants, suggesting that tet (S) is encoded on a chromosome of $L$. garvieae and transferred by unknown transfer elements.

This is the first demonstration that the tet $(\mathrm{M})$ and tet $(\mathrm{S})$ genes can be transferred from marine bacteria to $E$. coli. This suggests that the flow of TC resistance genes can occur between marine bacteria and terrestrial or human intestinal bacteria. Future studies should clarify the mechanisms of gene transfer among marine bacteria and between marine and terrestrial bacteria for the various TC resistance genes.

\section{Acknowledgments}

This study was partly supported by Grants-in-Aid from the Japan Society for the Promotion of Science and the Ministry of Education, Culture, Sports, Science and Technology, Japan.

\section{References}

Aoki, T., T. Arai, and S. Egusa. 1977. Detection of R plasmids in naturally occurring fish-pathogenic bacteria, Edwardsiella tarda. Microbiol. Immunol., 21, 77-83.

Aoki, T., T. Satoh and T. Kitao. 1987. New tetracycline resistance determinant of $\mathrm{R}$ plasmid from Vibrio anguillarum. Antimicrob. Agents Chemother., 31, 1446-1449.

Chandrasekaran, S., B. Venkatesh and D. Lalithakumari. 1998. Transfer and expression of a multiple antibiotic resistance plasmid in marine bacteria. Curr. Microbiol. 37, 347-351.

Charpentier, E. and P. Courvalin. 1999. Antibiotic resistance in Listeria spp. Antimicrob. Agents Chemother., 43, 2103-2108.

Charpentier, E., G. Gerbaud and P. Courvalin. 1994. Presence of the Listeria tetracycline resistance gene tet (S) in Enterococcus faecalis. Antimicrob. Agents Chemother., 38, 2330-2335.

Chopra, I. and M. Roberts. 2001. Tetracycline antibiotics: mode of action, applications, molecular biology, and epidemiology of bacterial resistance. Microbiol. Mol. 
Biol. Rev., 65, 232-260.

Clewell, D.B., S.E. Flannagan and D.D. Jaworski. 1995. Unconstrained bacterial promiscuity: the Tn916Tn1545 family of conjugative transposons. Trends Microbiol., 3, 229-236.

De Barbeyrac, B., M. Dupon, P. Rodriguez, H. Renaudin and C. Bebear. 1996. A Tn1545-like transposon carries the tet $(\mathrm{M})$ gene in tetracycline resistant strains of Bacteroides ureolyticus as well as Ureaplasma urealyticum but not Neisseria gonorrhoeae. J. Antimicrob. Chemother., 37, 223-232.

DePaola, A., P.A. Flynn, R.M. McPherarson and S.B. Levy. 1988. Phenotypic and genotypic characterization of tetracycline and oxytetracycline-resistant Aeromonas hydrophila from cultured channel catfish (Ictalurus punctatus) and their environments. Appl. Environ. Microbiol., 54, 1861-1863.

Francois, B., M. Charles and P. Courvalin. 1997. Conjugative transfer of tet $(\mathrm{S})$ between strains of $E n$ terococcus faecalis is associated with the exchange of large fragments of chromosomal DNA. Microbiology, 143, 2145-2154.

Ho, S.P., T.Y. Hsu, M.H. Chen and W.S. Wang. 2000. Antibacterial effect of chloramphenicol, thiamphenicol and florfenicol against aquatic animal bacteria. J. Vet. Med. Sci., 62, 479-485.

Kim, S.R., L. Nonaka, M.J. Oh, C.R. Lavilla-Pitogo and S. Suzuki. 2003. Distribution of an oxytetracycline resistance determinant tet (34) among marine bacteria isolates of a Vibrio species. Microbes Environ., 18, 74-81.

Kim, S.R., L. Nonaka and S. Suzuki. 2004. Occurrence of tetracycline resistance genes tet $(\mathrm{M})$ and tet $(\mathrm{S})$ in bacteria from marine aquaculture sites. FEMS Microbiol. Lett., 237, 147-156.

Levy, S.B. 1988. Tetracycline resistance determinants are widespread. ASM News, 54, 418-421.

Miranda, C.D., C. Kehrenberg, C. Ulep, S. Schwarz and M.C. Roberts. 2003. Diversity of tetracycline resistance genes in bacteria from Chilean salmon farms. Antimicrob. Agents Chemother., 47, 883-888.

Nonaka, L. and S. Suzuki. 2002. New $\mathrm{Mg}^{2+}$-dependent oxytetracycline resistance determinant Tet 34 in Vibrio isolates from marine fish intestinal contents. Antimicrob. Agents Chemother., 46, 1550-1552.

Perreten, V., F. Schwarz, L. Cresta, M. Boeglin, G. Dasen and M. Teuber, 1997. Antibiotic resistance spread in food. Nature, 389, 801-802.

Rhodes, G., G. Huys, J. Swings, P. McGann, M. Hiney, P. Smith and R.W. Pickup. 2000. Distribution of oxytetracycline resistance plasmids between aeromonads in hospital and aquaculture environments: implication of $\operatorname{Tn} 1721$ in dissemination of the tetracycline resistance determinant Tet A. Appl. Environ. Microbiol., $66,3883-3890$.

Rice, L.B. 1998. Tn916 family conjugative transposons and dissemination of antimicrobial resistance determinants. Antimicrob. Agents Chemother., 42, 18711877.

Roberts, M.C. 1996. Tetracycline resistance determinants: mechanisms of action, regulation of expression, genetic mobility, and distribution. FEMS Microbiol. Rev., 19, 1-24.

Salyers, A.A., N.B. Shoemaker, A.M. Stevens, and L.Y. Li. 1995. Conjugative transposons: an unusual and diverse set of integrated gene transfer elements. Microbiol. Rev., 59, 579-590.

Sandaa, R.A., V. Torsvik and J. Goksøyr. 1992. Transferable drug resistance in bacteria isolated from fish farm sediments. Can. Microbiol., 42, 1061-1065.

(Received February 2006, Accepted June 2006) 